\title{
ECONOMIC DEVELOPMENT OF THE MODERN WORLD AND REVIEW OF THE THEORY OF DEVELOPMENT
}

The subject of the article is the most well-known theories of economic development, which describe tools and strategies for achieving sustainable development of society.

Methods and methodology. When considering and analyzing well-known theories and strategies of economic development, methods of social, cultural, political comparison of some aspects of the impact of these theories on the economic life of society, systemic and institutional analysis of their changing interaction over time in a particular country were used. It is noted that by focusing on one of the only factors, it is not possible to determine the guaranteed success in the development of new concepts of growth strategy.

Results. As a result, it is noted that in order to achieve an optimal level of coordination, economists should conduct a generalized analysis of investment programs for government regulation and assess the attitude of a wide competent public to this. It is emphasized that the early development models, the "big push" strategy fell out of favor when the world witnessed the collapse of the centrally planned economy and slow growth. It is also noted that the dependence of these models on international trends was pursued by an internal orientation associated with development models, which suffered a collapse of state-encouraged production, entered as a neoclassical counterrevolution of the free market, privatization and export expansion that did not lead to anything.

Conclusions. All of this indicates that there is no single path of economic development that can be taken by all countries and, in the long term, the process of economic development requires changes in policy in order to take into account new emerging factors and trends.

The novelty of the article is the study of early ideas about the nature of economic prosperity, consideration of classical theories with four main groups: linear stages of growth models; models of structural change; dependence of these models on international trends; analysis of some aspects of neoclassical counterrevolutionary models, as well as the theory of growth and impaired coordination.

Practical and/or theoretical significance. The results obtained will be used in the future to develop the conceptual foundations of socio-economic models for the development of the national economy for sustainable development.

Key words: goals of economic development, theories of economic development, developing countries, classical theories, modern theories.

JEL Classification: O 10, O 50.

\section{Abdallah ALSHAMSI,} Dissertator

Azerbaijan State University of Economics

xxalshamsixx@hotmail.com orcid.org/0000-0001-6170-1765
Introduction (problem setting). In the modern world, with the intensification of globalization processes, great changes have taken place. Significant progress has been made in many areas critical to human well-being. Despite this, countries with developing economies are still experiencing serious economic difficulties, and the number of people living in absolute poverty has increased.

When designing these economic development strategies, it is also necessary to take into account the social, cultural, political aspects, systems and institutions, as well as their changing interactions over time in a given country. Research has shown that focusing on one single factor cannot guarantee success in the development process. Thus, investment in industry is necessary, but agriculture should not be neglected. Let us consider this on the example of the Republic of Azerbaijan.

As you know, the changes that have occurred in the sectoral structure of Azerbaijan's economy over the years of sovereignty have led to a number of contradictions between the enormous potential of the republic's economy and the existing sectoral structure. First of 
all, these changes are associated with the main structure-forming industries such as industry, agriculture and the service sector. The reforms carried out in the republics over the past 20 years have stimulated the inflow of foreign capital, most of which was directed to the extractive industry, which was reflected in the structure of the republic's GDP (Babaeva, 2018).

Note that the history of the economic development of Azerbaijan, the specific features of the republic and the natural-geographical location and demographic data determine the dependence of economic growth on both the state of industrial production and the development of agriculture.

The purpose of the article is to review and analyze some of the most prominent theories of economic development, which describe the tools and strategies for achieving sustainable development.

Review of recent publications. According to scientists, the general pattern of changes in the sectoral structure of the world economy is a consistent transition from a high share of agriculture, extractive industry, manufacturing industries to technically relatively simple industries (light, food industry), capital and material-intensive industries (metallurgy, chemical industry) and finally, to knowledge-intensive industries that create products based on high technologies (Stiglits, Sen, Fitussi, 2016).

The foregoing indicates the complexity and multifacetedness of the problems of economic development, for the solution of which a number of theories, explanations and arguments have been developed. The study of theories of international development suggests that economic development is a multidimensional process that involves interaction between different development goals and, therefore, requires systematic strategy development.

Although development economics took root as a discipline in economics half a century ago, economic prosperity has been addressed by such classics of economics as Adam Smith and Karl Marx (Stiglits, Sen, Fitussi, 2016). According to Smith, the wealth of nations is "focused on the market" and the correct division of labor can create more productive processes, while strengthening the national economy. Thus, wealth depends on specialization and exchange. Adam Smith argued that in a competitive environment, private investors, in pursuit of their own interests, are guided by the principle of the "Invisible Hand", which maximizes results at the national level and thereby contributes to the development of the public. The invisible hand doctrine became the foundation of capitalism (Skousen.pdf, 2021). However, free capitalism is often criticized for bringing wealth only to the rich while the poor get poorer.

On the other hand, Karl Marx in the "capital" (original work published in 1867), argued that the wealth of the capitalists comes from the exploitation of the surplus value created by the workers (Sukharev, 2007). Consequently, private property and the free market were seen as the causes of poverty for many millions of workers. Therefore, private property must be completely abolished. A national economy must be planned and managed by the state in order to meet the interests of the population. But the philosophy of socialism was also not viable. The collapse of the Soviet Union in 1991 demonstrated that the central planning model did not solve the problems of poverty and inequality.

Whereas prior to the $1970 \mathrm{~s}$, rapid economic growth was considered the main hallmark of development, since 1970 the concern of millions of people living off their livelihoods has attracted the attention of economists (Shokin, 1978).

Many of the developing countries have recorded high GDP rates, but little has changed in the living conditions of a large part of the population.

Given this situation, the question arises, is economic growth a development goal? Research shows that, in emerging economies, growth in gross national income and income per capita is accompanied by an increase in poverty, inequality and unemployment. Illness, malnutrition and death that occur in the daily lives of people in developing countries have dramatically changed the perception of development goals. Thus, the British economist Dudley Seers, having studied the economies of developing countries, noted that development cannot be limited to economic growth and the main goal of economic development is to reduce poverty, inequality and unemployment.

The concept of the Nobel laureate in economics Amarantia Sena has led to the broadest perspective of development goals (United Nations General Assembly, 1991). According to Sen, the ultimate goal of development is human empowerment, not just material or economic well-being. Thus, according to the Seine, a higher income is necessary, but not sufficient in terms of improving the quality of life of the population. According to his approach, the goals of economic development change from promoting production growth to promoting welfare (United Nations General Assembly, 1991). 
In the 1990s, economists increasingly recognized that it is the quality of life of the population that determines the economic status of the countries of the world.

In the report of the UN General Assembly "On world development. Development problems" it is indicated that "to improve the quality of life, especially in the poor countries of the world, requires higher incomes, which consists in better education, higher standards of health and nutrition, lower unemployment, resolution of environmental problems, greater personal freedom and a richer cultural life" (Acemoglu, Johnson, Robinson, 2001).

Presentation of the main material. The first generation of economic development models was formulated in the years after World War II. These early models focused on the usefulness of large capital injections to achieve rapid GDP growth. Two well-known models The Rostow stage growth model and the Harrod Domar model (Acemoglu, Johnson, Robinson, 2001).

Theorists of the second half of the last century viewed the development process as a sequence of historical stages. This performance was popularized by W. Rostow. Which, based on the historical model of developed countries of that period, proposed to single out three stages of growth, then he increased their number to five, and in 1971 added a sixth stage: traditional society, transitional society - the stage of "creating the prerequisites for take-off", the stage "take-off", The stage of "maturity" and the era of "high mass consumption". According to Rostow, the decisive stage is the take-off, through which developing countries will transit from an underdeveloped to a developed state, and the main criterion for the stage of "creating the prerequisites for take-off" is the "shock dose" of investments (Acemoglu, Johnson, Robinson, 2001). The Harrod-Domar theory also emphasized that the driving force of the economy is investment.

Although Rostow, Harrod and Domar were right about the important role of investment, which is most closely related to the economic growth rate, this is not enough for the sustainable development of the country (Acemoglu, Johnson, Robinson, 2001). For much of the 1960s and early 1970s, economists generally described the process of economic development in terms of structural change. Structural changes were accompanied by a process of labor redistribution, replacement of leading technological orders and creation of new opportunities for economic growth.

For much of the 1960s and early 1970s, economists generally described the process of economic development in terms of structural change. Structural changes were accompanied by a process of labor redistribution, replacement of leading technological orders and creation of new opportunities for economic growth.

Marginalists considered structural change by identifying industry imbalances. With the emergence of macroeconomics, Keynesianism and the Chicago School, the analysis of the structure of the economy is expressed in models of economic growth (one-factor models by R. Harod and E. Domar; multivariate neoclassical models based on the apparatus of production functions according to R. Solow; two-factor models of economic development by W. Lewis, J. Fairy, G. Rannis and others). Based on the works of T. Schultz, representatives of the neoinstitutional school of $\mathrm{H}$. Becker, economics began to describe structural changes and problems of economic growth using the concept of the presence of several basic sectors, including the sector of human capital reproduction (Acemoglu, Johnson, Robinson, 2001).

Thus, according to the British economist W. Lewis, in order to modernize the economy and achieve sustainable economic development, a process of redistributing resources from the agricultural sector to the industrial one is necessary. In this case, it is necessary to solve two main problems: firstly, accumulation (i. e., mobilizing savings and turning them into investments), and secondly, employment (Banerjee, Iyer, 2005).

According to the Lewis model, the labor force should move from the agricultural sector to the industrial sector. By getting rid of surplus labor in the agrarian sector, it is possible to achieve an increase in the marginal productivity of labor, which will lead to higher wages, an increase in total costs and the replacement of manual labor by machine labor. Under such circumstances, the mechanism of economic growth in industry and agriculture is predetermined. These two types of economic development correspond to two different investment functions. In industry, it is mainly about the expansion of capital. This investment function, which is basically Keynesian, depends on the demand for the final industrial product. With a stable wage, it leads to an increase in profits and investment. On the contrary, in agriculture, the investment function manifests itself according to Schumpeter's definition: a decrease, not an increase in profits leads to investment in this industry. An increase in wage costs reduces profits, and, consequently, the purpose of investment is to replace manual labor with machine labor in order to reduce costs and increase profits (Banerjee, Iyer, 2005). 
At the same time, the Lewis model had its drawbacks. So, because the redistribution of labor from the agricultural sector to the industrial sector is considered the engine of economic growth, many developing countries are pursuing policies that often promote industrial development while neglecting agriculture.

Another indisputable factor of economic growth is urbanization. Thus, the World Bank report "on global monitoring" for 2013 noted that countries and regions with a high level of urbanization are ahead of other states in achieving the goals set at the Millennium Summit (Bardhan, 2006). One of the authors of the Global Monitoring Report, Jos Verbeek, identified the reasons why the pace of social development in cities is higher than in rural areas. In his opinion, "Cities are centers of economic activity, economic growth and job creation. Consequently, the poverty rate is much lower in cities than in rural areas" (Banerjee, Iyer, 2005). But at the same time, we must not forget that uncontrolled population growth in cities can quickly lead to the emergence of slums, so the government must pursue the correct urban planning policy.

In addition, in both cities and provinces, one of the important development factors is improving the efficiency of health care and social services. Since the late 1960s, policymakers have shifted their focus to human capital development. The World Bank recommends that countries with significant reserves of oil and other minerals use the proceeds from the sale of these resources to finance health and education.

Studies of structural transformations show that, when carrying out structural policies, special attention was paid to models of economic development, while it was suggested that the structure of the economy is similar in all countries and is identifiable.

Thus, in the 60s and 70s, American researchers developed a model of economic growth with two deficits, which is a system of medium and long term regressive models, where the growth rate is determined depending on the deficit of either internal or external resources. The purpose of this model is to identify the relationship between domestic savings and external sources of funding, as well as in the crowding out of external resources by internal ones.

In the 1980s, neoclassical counterrevolutionary economists identified three main factors for sustainable economic growth: the demand factor, the supply factor, and the distribution factor.

In the early $80 \mathrm{~s}$ of the last century, the international theory of dependence was very popular. The historical roots of addiction theory go back to debates about free, trade, protectionism, and the issues of imperialism and colonialism. Even the 19th century German economist, Friedrich List, argued that free trade reinforces backwardness and perpetuates the advantages of developed countries. According to the Latin American revolutionary Ernesto Che Guevara, the inflow of capital from developed countries to the periphery is nothing more than the establishment of economic dependence. Thus, dependency theorists have argued that backwardness exists due to the dominance of developed countries and multinational corporations over developing countries. It has been argued that the undeveloped states of the "periphery" become poorer as a result of the fact that their resources and capital flow to the rich countries of the "center". Thus, due to dependence, developing countries cannot achieve sustainable growth. According to the professor of the London School of Economics Maitrish Ghatak, developing countries should end dependence by breaking economic relations with the developed world.

In contrast to the international model of dependence, neoclassical counterrevolutionary economists advocated the free market. In their view, the backwardness of the "periphery" is not the result of the predatory activities of developed countries and international institutions, but rather was caused by intense state interference, subsidies, state property and corruption (Meier, 2000). So, neoclassical economists saw the way out for developing countries by market liberalization, stabilization and privatization.

A new growth theory emerged in the 1990s. New growth theorists (Romer, 1986; Lucas, 1988; Agion and Howitt, 1992) argue that economic growth is the result of increased returns from the use of knowledge rather than labor and capital. In their opinion, it is investment in human capital (education), research and development $(\mathrm{R} \& \mathrm{D})$ that can ensure sustainable economic growth.

In the early $1990 \mathrm{~s}$, the theory of coordination gained particular popularity. The issues of coordination between complementary industries were first raised by Rosenstein-Rodan, who back in 1943 in his article "Problems of Industrialization of Eastern and Southeastern Europe" formulated the theory of the "big push". Professor of the University of California H. Leibenstein paid special attention to investments. Thus, in his book "Economic Backwardness and Economic Growth", he indicated the size of the minimum investment required for the development of the economy. R. Nurkse, in his "theory of balanced growth", proposed to modernize the economy by investing in various sectors of the economy, in his opinion, the synchronization of capital injection into production sectors will allow achieving self-sustaining growth, overcome the 
narrowness of the domestic market, and stimulate the expansion of entrepreneurship. A. Hirschman in his book "Strategy for Economic Development" proposed an alternative concept of unbalanced growth, where he proposed to invest in various industries pointwise. Professor of the University of Sussex H. Singer, developing the ideas of A. Hirschman and R. Nurkse, proposed to increase labor productivity in agriculture and in traditional export industries through import substitution and the development of our own production and social infrastructure (Myrdal, 1992).

In order to achieve an optimal level of coordination, economists have proposed a massive investment program regulated by the state and under the leadership of the public. Like early development models, the big push strategy fell out of favor when the world witnessed the collapse of the centrally planned economy and slow growth. Professor of Stockholm University G. Myrdal noted that in developing countries prices and factors of production very weakly respond to supply and demand and to economic incentives in general, there is a high level of monopolization in the market, the bureaucratic system pursues its own interests, which means that the positive effect of large capital injections in the framework of the theory of the "big push" is limited (Shirley, 2005).

Carla Hoff, a professor at Columbia University and a leading economist at the World Bank, described the economy as a shared ecosystem in which "evil preferences can become an obstacle to cooperation, trade, and therefore economic development" (UNFAO, 2006).

Modern economists studying development problems have come to the following conclusions: 1) the market does not coordinate everything and there are uncertainties in the market mechanism; 2) the firm's performance depends not only on its own efforts and abilities, but many factors influence its productivity (for example, macroeconomic factors, the environment, corruption and the legal system); 3) when the market mechanism does not work, an active role of the government is necessary, since it is the government that can coordinate the activities of firms and achieve balance (World Bank, 2008).

However, the theory of coordination failure has been criticized for its overemphasis on the role of government. Critics argued that the government's economic policies were ineffective and that the government could be misdirected, as models of failed coordination lacked details on how the government could coordinate the country's economy.

Conclusions. So, the models of international dependence pursued an internal orientation, the development model that encouraged state production collapsed, the neoclassical counter-revolution of the free market, privatization and export expansion did not bring the expected results.

All this indicates that there is no single path of economic development that can be taken by all countries and, in the long term, the process of economic development requires changes in policy in order to take into account new emerging factors and trends.

\section{References:}

1. Babayeva, A.N. (2018), Babaeva, A.N. Sovremennoye sostoyaniye promyshlennosti Azerbaydzhana: analiz i otsenka [The current state of the industry in Azerbaijan: analysis and assessment]. Baku: Avropa Publishing House [in Russian].

2. Stiglits, D., Sen, A., Fitussi, ZH.-P. (2016). Neverno otsenivaya nashu zhizn': pochemu VVP ne imeyet smysla? Doklad Komissii po izmereniyu effektivnosti ekonomiki i sotsial'nogo progressa $=$ Mismeasuring our lives: why GDP doesn't add up [Misjudging Our Lives: Why Doesn't GDP Make Sense? Report of the Commission on Measuring Economic Performance and Social Progress = Mismeasuring our lives: why GDP doesn't add up] / transl. from English I. Kushnareva; ed. by T. Drobyshevskaya. Moscow: Publishing house of the Gaidar Institute [in Russian].

3. Skousen, M. (2007). The big three in economics: Adam Smith, Karl Marx, and John Maynard Keynes. Retrieved from: http://www.library.fa.ru/files/Skousen.pdf [in English].

4. Sukharev, O.S. (2007). Ekonomicheskaya politika. Problemy teoreticheskogo opisaniya i prakticheskoy realizatsii [Economic policy. Problems of theoretical description and practical implementation], in 2 vol. Moscow: Ekonomika [in Russian].

5. Retrieved from: https://mediasrv.aua.gr/eclass/modules/document/file.php/AOA215/Economic\%20 Development\%20-\%20Todaro\%20and\%20Smith.pdf [in English].

6. Shokin, N.A. (1978). O sootnoshenii sotsial'noy i ekonomicheskoy effektivnosti sotsialisticheskogo narodnogo khozyaystva i predposylkakh ikh povysheniya [On the relationship between the social and economic efficiency of the socialist national economy and the prerequisites for their increase]. Izv AN SSSR, Seriya ekonomika - Izv of the USSR Academy of Sciences, Series of Economics, no. 3, pp. 35-49 [in Russian]. 
7. United Nations General Assembly (1991). Otchet General'noy Assamblei OON "O mirovom razvitii. Problemy razvitiya" [Report of the UN General Assembly "On world development. Development problems"]. [in Russian].

8. Acemoglu, D., Johnson, S., and Robinson, J.A. (2001). The Colonial Origins of Comparative Development: An Empirical Investigation. American Economic Review, vol. 91(5), pp. 1369-1401 [in English].

9. Banerjee, A.V., Iyer, L. (2005). History, Institutions, and Economic Performance: The Legacy of Colonial Land Tenure Systems in India. American Economic Review, vol. 95(4), pp. 1190-1213 [in English].

10. Bardhan, P. (2006). Institutions and Developmen". The Elgar Companion to Development Studies / D. Clark (ed.). Cheltenham: Edward Elgar Publishing, pp. 2-56 [in English].

11. Myrdal, G. (1992). The Equality Issue in World Development. Nobel Lectures, Economics, 1969-1980/ A. Lindbeck (ed.). Singapore: World Scientific Publishing [in English].

12. Shirley, M.M. (2005). Institutions and Development. Handbook of New Institutional Economics / C. Ménard and M.M. Shirley (eds.). New York: Springer [in English].

13. UNFAO, (2006). Land Reform. Retrieved from: http://www.fao.org/sd/Ltdirect/landrF.htm [in English]

14. World Bank, (2008). World Development Report, 2008. New York: Oxford University Press [in English].

\title{
ЕКОНОМІЧНИЙ РОЗВИТОК СУЧАСНОГО СВІТУ ТА ПЕРЕОСМИСЛЕННЯ ТЕОРІЙ РОЗВИТКУ
}

\author{
Абдалла АЛЬШАМСІ, \\ дисертант \\ Азербайджанського державного економічного університету \\ xxalshamsixx@hotmail.com \\ orcid.org/0000-0001-6170-1765
}

\begin{abstract}
Об’єктом статті є найбільш відомі теорії економічного розвитку, які описують інструменти та стратегії для досягнення сталого розвитку суспільства.

Методи і методологія. У процесі розгляду відомих теорій і стратегій економічного розвитку використані методи соціального, культурного, політичного порівняння деяких аспектів впливу цих теорій на економічне життя суспільства, системний та інституціональний аналіз змін їх взаємодії з плином часу в тій чи іншій країні. Зазначається, щңо шляхом зосередження уваги на одному з факторів неможливо визначити гарантованість успіхів у розробленні нових конщептів стратегії зростання.

Результати. Визначається, щзо з метою досягнення оптимального рівня координації вчені-економісти повинні провести узагальнений аналіз інвестиційних програм регулювання державою та оцінити ставлення до иього широкої компетентної громадськості. Підкреслюється, що ранні моделі розвитку, стратегія «великого поштовху» натепер не актуальні, адже у світі спостерігається крах иентралізованої планової економіки та повільного зростання. Також встановлюється, що залежність иих моделей від міжнародних трендів переслідувала мету внутрішньої спрямованості, пов'язаної з моделями розвитку, які зазнали невдачі, заохочуваного державою виробництва, неокласичної контрреволюиії вільного ринку, приватизації та розширення експорту, що не дало очікуваних результатів.

Висновки. Наведене вказує на те, що немає єдиного шляху економічного розвитку, яким могли би скористатися всі країни, у довгостроковій перспективі процес економічного розвитку вимагає внесення змін у політику, щоб вести облік нових факторів і тенденцій, щь виникають.

Новизною в статті $\epsilon$ дослідження ранніх уявлень про природу економічного процвітання, розгляд класичних теорій із чотирма основними групами (лінійними етапами зростання моделей, моделями структурних змін, залежністю изих моделей від міжнародних трендів, аналізом деяких аспектів неокласичних контрреволюиійних моделей), а також теорії зростання й порушення координації.

Практична та/або теоретична значимість. Отримані результати надалі будуть використані для розроблення концептуальних основ соціально-економічних моделей розвитку національної економіки зі сталим розвитком.
\end{abstract}

Ключові слова: цілі економічного розвитку, теорії економічного розвитку, країни, що розвиваються, класичні теорії, сучасні теорії. 